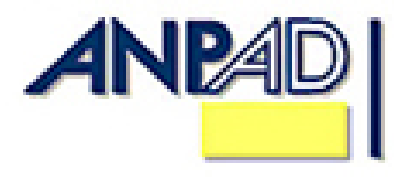

Available online at http://www.anpad.org.br/bar

BAR, Rio de Janeiro, v. 11, n. 2, art. 1, pp. 125-144, Apr./June 2014

$(\mathrm{ccc}) \mathrm{E}$

\title{
Parallel Careers and their Consequences for Companies in Brazil
}

Maria Candida Baumer Azevedo E-mail address: mariacandida@ peopleandresults.com.br

Open University of the Netherlands Open Universiteit, Valkenburgerweg 177, 6419 AT Heerlen, the Netherlands.

Received 5 October 2012; received in revised form 20 August 2013 (this paper has been with the authors for four revisions); accepted 21 August 2013; published online $1^{\text {st }}$ April 2014. 


\begin{abstract}
Given the relevance of the need to manage parallel careers to attract and retain people in organizations, this paper provides insight into this phenomenon from an organizational perspective. The parallel career concept, introduced by Alboher (2007) and recently addressed by Schuiling (2012), has previously been examined only from the perspective of the parallel career holder ( $\mathrm{PC}$ holder). The paper provides insight from both individual and organizational perspectives on the phenomenon of parallel careers and considers how it can function as an important tool for attracting and retaining people by contributing to human development. This paper employs a qualitative approach that includes 30 semi-structured one-on-one interviews. The organizational perspective arises from the 15 interviews with human resources (HR) executives from different companies. The individual viewpoint originates from the interviews with 15 executives who are also PC holders. An inductive content analysis approach was used to examine Brazilian companies and the Brazilian office of multinationals. Companies that are concerned about having the best talent on their teams can benefit from a deeper understanding of parallel careers, which can be used to attract, develop, and retain talent. Limitations and directions for future research are discussed.
\end{abstract}

Key words: parallel careers; parallel career holders; talent attraction; development; retention. 


\section{Introduction}

The concept of parallel careers, or slash careers, is defined as having more than one professional career at the same time regardless of the amount of time devoted to each, whether the careers are related, whether financial compensation is earned, and whether the individual has an employer or is self-employed (Alboher, 2007). A parallel career is not a secondary job or a hobby, although the latter can become a parallel career with the addition of professional relations; the other part of the career relationship (the recruiter, boss, or client) has hiring or contracting options in addition to the person in question. The concept of parallel careers should not be confused with the dual career ladder, which is an option for a linear plan of career development that offers professionals, from a certain level of seniority upward, ascending mobility without requiring them to be in supervisory or management positions to grow hierarchically (Cesare \& Thornton, 1993; Libera, 2011; Noe, 2002).

There is a gap in the literature due to a lack of previous research on this topic. Alboher (2007) used qualitative research based on an analysis of interviews with 32 PC holders to identify their experiences. Recently, Schuiling (2012) conducted a similar study that included additional cases of individual PC holders. The present study is the first to consider the company perspective.

This research examines how companies located in Brazil understand the need of some professionals to hold parallel careers. Brazil is considered because Brazilians usually work while studying. In contrast to other countries where serious work is begun after graduation, in Brazil, individuals begin their formal careers during their early college years. This study examines whether and how PC holders add value to businesses through their multiple careers. The research identifies the benefits and disadvantages of allowing and encouraging simultaneous careers for the holder as well as for the company (or companies) for which the PC holder works.

The research questions of this study consider companies' attitudes toward parallel careers, whether companies recognize such cases in their organizational charts, the most common combinations, reasons for parallel careers, and the benefits and drawbacks of parallel careers for companies and PC holders.

\section{Theoretical Background}

\section{Changes in the employment context}

In the 1990s, globalization, deregulation, and rapid advances in technology changed the landscape in most industries. These conditions led to widespread organizational change driven by the need to address international competition, economic and market shifts, and mergers and acquisitions (Doherty, 1996). Many organizations downsized, becoming leaner to improve productivity and performance (Greenhalgh \& Rosenblatt, 2010). Downsizing reappeared during the second half of the 2000-2010 decade with the global economic crises (Krugman, 2009), becoming an integral part of organizational life (Datta, Guthrie, Basuil, \& Pandey, 2010).

Employees' sense of loyalty was affected by the labor market deregulation that occurred during this period (Boulhol, 2009). Loyalty had thus far been the major force affecting the relationship between professionals and employers. This relationship, based on job security and commitment, was replaced by work insecurity and a decline in loyalty (Greenhalgh \& Rosenblatt, 2010; Herriot \& Pemberton, 1995; Robbins, 1999). This change affected those who were laid off as well as those who stayed with companies (Robbins, 1999). Many survivors felt that organizations violated the terms of their implicit psychological contracts (Appelbaum, Bethune, \& Tannenbaum, 1999; Greenhalgh \& Rosenblatt, 2010). This sentiment contributed to a shift from a "one career, one single company" path to a path involving employment with several organizations throughout life, and the focus shifted from 
the company to the individual's career (Klehe, Zikic, Van Vianen, \& De Pater, 2011; Reilly, Brett, \& Stroh, 1993; Wajcman \& Martin, 2001).

With this shift, power also shifted from corporations to the workers (Michaels, Handfield-Jones, \& Axelrod, 2001). Hiring talented professionals became more expensive. To attract these professionals, companies had to work harder (Michaels et al., 2001) because employability became the focus for individuals (Hay, 2002; Nilsson \& Ellstrom, 2011). Under these conditions, higher wages and superior remuneration packages lost their primacy as retention tools (Earle, 2003; Moncarz, Zhao, \& Kay, 2009; The Economist, 1999).

In the Information Age, individuals began to have access to unlimited information on job availability. Their loyalty shifted from the company to the career (Rynes \& Cable, 2003; Wajcman \& Martin, 2001). This change led many people to shift their organizational careers toward a more protean and/or boundaryless approach (Briscoe \& Finkelstein, 2009).

\section{Protean and boundaryless careers}

The concept of the protean career was introduced by Hall $(1976,2004)$ as a process managed by the person, not the organization. A protean career consists of an individual's varied experiences in education, training, work in various organizations, and changes in occupational field. The protean person makes his/her own career choices, identifying the search for self-fulfillment as an integrative element of life. The individual is value driven and self-directed (Briscoe \& Hall, 2006). Because it is shaped and driven by the individual, the protean career may be redirected; the goal is to meet the needs of the person as he and the environment change (Hall, 1976, 1996). The pursuit of the protean career requires a high level of self-awareness and personal responsibility. Many people cherish this autonomy, but others find this freedom terrifying, experiencing it as a lack of external support. A developmental or learning process is required for adaptation (Hall, 1996). As such, the protean career has commonly been characterized as highly adaptive, flexible, and self-directed with regard to the pursuit of psychological success (Greenhaus, Callanan, \& DiRenzo, 2008).

The boundaryless career has been characterized by Arthur (1994), DeFillippi and Arthur (1994), Arthur and Rousseau (1996), and Sullivan and Arthur (2006), as independent of traditional organizational career arrangements. Its transposed boundaries may be physical or psychological. Movement across organizations and employers or across traditional hierarchical reporting and hierarchical advancement principles testifies to the lack of physical boundaries. An absence of psychological barriers emerges when validation and marketability are drawn from outside of the present employer. This lack of psychological barriers is sustained by external networks, rejecting career opportunities for personal or family reasons, or perceiving a boundaryless future regardless of structural constraints (Arthur, 1994; Segers, Inceoglu, Vloeberghs, Bartram, \& Henderickx, 2008; Sullivan \& Arthur, 2006).

In both cases, success is measured internally and is evaluated psychologically rather than objectively through a focus on external success in terms of aspects such as pay, rank, or hierarchical position (Briscoe, Hall, \& DeMuth, 2006; Verbruggen, 2012). Success is a matter of value-driven orientation; personally meaningful goals are pursued instead of socially imposed ones. Personally meaningful goals provide the motivation for career decisions and create standards for the experience of psychological career success (Briscoe et al., 2006). All of these aspects represent a significant change from the traditional career, which typically develops within the confines of an employment setting and is characterized by hierarchical advancement (Arthur \& Rousseau, 1996; Sullivan, 1999; Sullivan \& Baruch, 2009).

\section{Parallel careers}

Parallel careers, or slash careers, as Alboher (2007) called them, suggest a balance between more than one professional career and the spreading of commitment among these careers. According 
to Alboher, the major difference between changing careers and slashing is that individuals who slash do not abandon their primary vocation; they enhance or reconfigure it.

A career is related to professional activities rather than to extracurricular interests or a hobby. A career does not necessarily have to produce income (Alboher, 2007). Parallelism suggests a focus on balancing multiple vocations and spreading commitment among them rather than primary and secondary engagement (Kirton, 2006). The amount of energy and time devoted to each career may change according to the success achieved and the life stage of the individual (Alboher, 2007). It is possible for individuals to simultaneously hold several parallel careers and to affiliate with and commit to them in more or less equal proportions (Layder, 1993).

To obtain a deep understanding of the concept of parallel careers, it is important to distinguish parallel careers from the holding of multiple jobs. Merely holding multiple jobs means that a person performs practically the same work for different organizations or employers. This circumstance is called a secondary labor market (Averett, 2001; Shishko \& Rostker, 1976). An example would be a nurse working for two or more different hospitals at the same time. In this case, the content of the work is similar or even equivalent. In the case of parallel careers, the content may be related or complementary, but it is not the same.

People may opt for parallel careers for the following reasons:

1. Financial purposes - A way of increasing financial achievement to afford regular life expenses, pay off debts, or save money for a specific goal (Amirault, 1997; Lundborg, 1995; Martel, 2000; McCormick, 2003). This aim is accomplished by working in a different field. Otherwise, it would be a matter of merely having a second job in the same field.

2. Career change prior step - This step becomes necessary when the intended field is intensely competitive and difficult to enter (Amirault, 1997; Livanos \& Zangelidis, 2012). This aim may be accomplished by freelancing, volunteering, or obtaining temporary or internship positions in the desired career field. An individual completes this phase before quitting his or her current job and searching for a full-time position in the intended field. This method acquaints the individual with the new area and provides some assurance regarding his enjoyment of and ability to succeed at the new career. The change to the desired field may involve working for a new company or being selfemployed and following an entrepreneurial path (Martel, 2000). This step is a way of reducing the risk of regret and failure.

3. Income security - Holding multiple jobs may be a response to perceived job insecurity and may act as a hedge against unemployment (Bell, Hart, \& Wright, 1997). Having a parallel career is a backup plan if an individual loses his or her current job. It includes revenue-producing activities that are not related to the day job and that will continue undisturbed if the day job disappears (Marion, 2009). In terms of investment, diversifying is always a smart path, and the same applies for career time investment. In both areas, diversification is a way to be protected from (or decrease the risk of) the fluctuation of a particular industry (James-Enger, 2010). A parallel career may also be a method of bolstering uncertain income (Wu, Baimbridge, \& Zhu, 2009). An example would be a realtor who is also a teacher to reduce the income risk of the first occupation.

4. Help - Friends or relatives may need physical or intellectual professional assistance (Martel, 2000).

5. Work chosen condition - This condition occurs among people with higher education and incomes (Amirault, 1997) and involves different sources of relationships, knowledge, learning moments, and experiences. Such a choice can be an alternative to an uninteresting, unsatisfying paid work career (Bradley, Healy, \& Mukherjee, 2005). It is a way to satisfy personal interests that cannot be fulfilled by only one career (McCormick, 2003). Having two occupations enables individuals to engage in activities of particular interest to them (Wu et al., 2009), have fun and enjoy a second activity (Martel, 2000), and explore their career potential in different fields of interest (Amirault, 1997). Many people find that their skills and knowledge are in demand, that their work schedule permits a second activity, or that their hobbies and interests have earning potential in an area 
external to a primary career or employer (Amirault, 1997). In these cases, motivation originates from the opportunity itself, not from the extra earnings.

According to McCormick (2003), the trend toward a parallel career as a work chosen condition partly reflects the short attention spans of Generation X workers, who crave greater task variety than they could attain from a single job. Kimmel and Conway (2001) call this rationale the heterogeneous jobs or job-packaging motive. In addition, there is a desire for more flexibility and less restrictive work environments. Jennifer Thompson notes, "Those individuals are seeing that they have a variety of interests or passions, and a two-track career allows them to pursue more of those passions" (as cited in McCormick, 2003, p. 2).

Parallel careers appear to be a recognized phenomenon in the literature (Alboher, 2007) with regard to the perspective of PC holders. Thus far, however, the literature has not addressed organizations' perceptions of and reactions to this subject. This study aims to redress this gap in the literature by performing an analysis using semi-structured, in-depth interviews with HR leaders and PC holders regarding their thoughts on parallel careers and how they address the issue when an employee becomes a PC holder or vice versa.

\section{Methodology}

\section{Data collection}

For this exploratory study, a qualitative approach was employed (Cooper \& Schindler, 2008). The project was completed in 2011-2012. The study aimed to analyze different companies' perspectives and to find meaningful patterns related to the subject. To accomplish this aim, the study considered 15 companies from different sectors, incorporating 30 respondents ( 15 heads of HR, and 15 PC holders) located in São Paulo (14 companies) and Paraná (one company). The company in Paraná was added to the sample after it was discovered that it had a structured program to stimulate parallel careers.

Semi-structured interviews were conducted with the heads of HR. Each interview lasted from 45 to 90 minutes. The purpose was to identify the companies' perceptions of and means of formally addressing this subject (referring to policies and practices). The survey also explored various combinations of parallel careers and the advantages and disadvantages of parallel careers for both the holder and the company. The companies interviewed were from the following sectors: media, trade, logistics, engineering, consulting, insurance, energy, textile, automotive, cement pharmaceutical, and consumer goods. The HR interviewees held the following positions: HR manager, HR general manager, director of HR, and HR VP. On average, the participants were 44.6 years of age, and the group included 14 women and 16 men.

A semi-structured format was used when interviewing the PC holders and workers at the companies. The purpose of these interviews was to explore the interviewees' perceptions of the subject and to examine the various careers combinations and their advantages and disadvantages with regard to the interviewees and the organization. Additionally, questions were asked about the existence or lack of practices, policies, or working tools to facilitate simultaneous careers. The PC holder interviewees held the following positions: CEO, the head of business unit, director, manager, consultant, coordinator, supervisor, and specialist in the legal, marketing, sales, training, logistics, accounting, and upper management departments.

The following questions were asked to the respondents: 
Table 1

Questionnaire Theoretical Background

\begin{tabular}{|c|c|c|c|}
\hline HR Executives & Theoretical background & PC holders & Theoretical background \\
\hline $\begin{array}{l}\text { What does the company } \\
\text { that you work for think } \\
\text { about parallel careers? }\end{array}$ & Alboher (2007) & $\begin{array}{l}\text { Which are your parallel } \\
\text { careers? }\end{array}$ & Alboher (2007) \\
\hline $\begin{array}{l}\text { Does the company that } \\
\text { you work for have } \\
\text { employees with parallel } \\
\text { careers? }\end{array}$ & Author's decision & $\begin{array}{l}\text { What do you think about } \\
\text { parallel careers? }\end{array}$ & Alboher (2007) \\
\hline $\begin{array}{l}\text { What are the most } \\
\text { common combinations of } \\
\text { parallel careers? }\end{array}$ & Author's decision & $\begin{array}{l}\text { Which are the practices, } \\
\text { policies, arrangements } \\
\text { offered by the company } \\
\text { that facilitate/make harder } \\
\text { having parallel careers? }\end{array}$ & $\begin{array}{l}\text { Richman, Civian, } \\
\text { Shannon, Hill and Brennan } \\
\text { (2008); Hill, Hawkins, } \\
\text { Ferris and Weitzman } \\
\text { (2001); Bond, Galinsky, } \\
\text { Stacy and Brownfield } \\
\text { (2005); Christensen and } \\
\text { Staines (1990); Felstead, } \\
\text { Jewson, Phizacklea and } \\
\text { Walters (2000); Hill et al. } \\
\text { (2001); Peters, } \\
\text { Bleijenbergh and } \\
\text { Oldenkamp (2009); } \\
\text { Friedman, Christensen and } \\
\text { DeGroot (1998); } \\
\text { Venkatesh and Johnson } \\
\text { (2002); Rau (2003); } \\
\text { Hobson, Delunas and } \\
\text { Kesic (2001); Pas, Peters, } \\
\text { Doorewaard, Eisinga and } \\
\text { Lagro-Janssen (2011); Hill } \\
\text { et al. (2008) }\end{array}$ \\
\hline $\begin{array}{l}\text { What are the reasons for } \\
\text { parallel careers? }\end{array}$ & $\begin{array}{l}\text { Lundborg (1995); } \\
\text { Amirault (1997); Bell et } \\
\text { al. (1997); Martel (2000); } \\
\text { McCormick (2003); } \\
\text { Bradley, Healy and } \\
\text { Mukherjee (2005); } \\
\text { Livanos and Zangelidis } \\
\text { (2012); Marion (2009); } \\
\text { Wu, Baimbridge and Zhu } \\
\text { (2009); James-Enger } \\
\text { (2010) }\end{array}$ & $\begin{array}{l}\text { Why do you have parallel } \\
\text { careers? }\end{array}$ & $\begin{array}{l}\text { Lundborg (1995); } \\
\text { Amirault (1997); Bell et } \\
\text { al. (1997); Martel (2000); } \\
\text { McCormick (2003); } \\
\text { Bradley et al. (2005); } \\
\text { Livanos and Zangelidis } \\
\text { (2012); Marion (2009); } \\
\text { Wu et al. (2009); James- } \\
\text { Enger (2010) }\end{array}$ \\
\hline
\end{tabular}


Table 1 (continued)

\begin{tabular}{|c|c|c|c|}
\hline HR Executives & Theoretical background & PC holders & Theoretical background \\
\hline $\begin{array}{l}\text { What are the benefits to } \\
\text { the person with parallel } \\
\text { careers? What are the } \\
\text { benefits for the companies } \\
\text { that support them? }\end{array}$ & $\begin{array}{l}\text { Sieber (1974); Marks } \\
\text { (1977); Brousseau, Driver, } \\
\text { Eneroth and Larson } \\
\text { (1996); Ryan and } \\
\text { Frederick (1997); } \\
\text { Friedman et al. (1998); } \\
\text { Schaufeli, Salanova, } \\
\text { González-Romá and } \\
\text { Bakker (2002); May, } \\
\text { Gilson and Harter (2004); } \\
\text { Greenhaus and Powell } \\
\text { (2006); Alboher (2007); } \\
\text { Bakker and Demerouti } \\
\text { (2008); James-Enger } \\
\text { (2010); Voydanoff (2001); } \\
\text { Lee and DeVoe (2012) }\end{array}$ & $\begin{array}{l}\text { What are the benefits for } \\
\text { you and the company? }\end{array}$ & $\begin{array}{l}\text { Sieber (1974); Marks } \\
\text { (1977); Brousseau et al. } \\
\text { (1996); Ryan and } \\
\text { Frederick (1997); } \\
\text { Friedman et al. (1998); } \\
\text { Schaufeli } \text { et al. (2002); } \\
\text { May et al. (2004); } \\
\text { Greenhaus and Powell } \\
\text { (2006); Alboher (2007); } \\
\text { Bakker and Demerouti } \\
\text { (2008); James-Enger } \\
\text { (2010); Voydanoff (2001); } \\
\text { Lee and DeVoe (2012) }\end{array}$ \\
\hline $\begin{array}{l}\text { What are the drawbacks to } \\
\text { both sides? }\end{array}$ & $\begin{array}{l}\text { Mackin (1995); Kimmel } \\
\text { and Powell (1996); } \\
\text { McCormick (2003); Kirton } \\
\text { (2006); James-Enger } \\
(2010)\end{array}$ & $\begin{array}{l}\text { What are the drawbacks to } \\
\text { both sides? }\end{array}$ & $\begin{array}{l}\text { Mackin (1995); Kimmel } \\
\text { and Powell (1996); } \\
\text { McCormick (2003); Kirton } \\
\text { (2006); James-Enger } \\
\text { (2010) }\end{array}$ \\
\hline
\end{tabular}

\section{Data analysis}

After the interviews were transcribed, an inductive content analysis approach was used to analyze the data (Cole, 1988; Krippendorff, 2012). Advantages and disadvantages were used as the initial categories to direct the analysis (Strauss \& Corbin, 2008).

To identify the open coding, the data collected were disaggregated into conceptual units and labeled. The result was a list of conceptual labels related to the lower level of focus (109 labels). These open codes were compared and placed into broader categories (69 categories). As relations between the broad categories were identified, they were arranged into a hierarchical form, leading to the formation of six primary categories. This step produced the conceptual categories examined in this paper. The findings are discussed in the next section, and each characteristic that was identified in relation to parallel careers is summarized.

\section{Findings}

The axial codes identified were as follows: companies' perspectives (regarding their reaction to PC holders in their domain), common combinations of parallel careers, reasons for parallel careers, benefits for companies and professionals, drawbacks of parallel careers, organizational levers, and barriers. The findings are organized around these primary categories.

\section{Companies' perspectives - recognition, allowance, and reaction}

The companies perceived the phenomenon of parallel careers differently. All of the companies recognized the existence of this phenomenon, but their permission and stimulus levels varied. The first pattern categorizes the companies according to their recognition, allowance, and reactions. 
Even the respondents who opposed parallel careers within their domain and who could not identify anyone with such a profile within their firm confirmed that they "heard about someone having one but did not investigate" or that "it is forbidden, but there is a case.... The person is close to the owner, and we have to overlook it."

The following combinations were identified: Recognized + Prohibited + None; Recognized + Permitted + None; and Recognized + Permitted + Promoted. The other possible matrix combinations were not found in any of the analyzed companies. Thus, the first category was named Against. Respondents in this category recognized the existence of parallel careers but opposed them, perceiving them as a loss of energy, focus, and time. According to these respondents, all human resources should focus only on the company. The second group, called Indifferent, also recognized the presence of PC holders among their employees. In this case, there were no obstacles to their existence as long as the person delivered the expected results. The third group, called Promoter, recognized parallel careers as part of modern corporate life and promoted them internally. These respondents perceived and gained advantages from the phenomenon.

"It is not forbidden. We are very open to diversity. The company even encourages it. Our magazines hire our own employees to write as free-lancers.... Of course, there is a formal work contract, but the nature of the work of a journalist ... You go to the street, write at home.... Our employees are very diverse - clothing, tattoos, flip-flops - it is accepted and desired here. It makes having parallel careers natural." (HR Director).

\section{Common combinations}

Different arrangements were found among the PC holders. The most common was the combination of one career with a teaching career. A justification for this combination is the perception among human resources that teaching does not present risks of employee loss, time competition, or any other threat.

"The academic career is well seen here. It is less threatening to the company. The working hours are defined; one thing does not interfere with the other." (HR Director).

Other examples are combinations of a corporate career and an occupation as one of the following: columnist, consultant, craftsman, doctor, entrepreneur, farmer, lobbyist, musician, nurse, seller, translator, or writer.

"There are many doctors who are executives here and have a clinic or work in a hospital during the evenings or weekends. And it is okay, it is declared. There is a formal statement signed." (HR VP).

\section{Reasons for parallel careers}

The respondents' reasons for parallel careers support those identified during the literature review, including financial needs (a second source of income), the first step in a career change, pleasure (work chosen condition), and offering assistance to others were all found to be reasons for parallel careers. The only reason that was not identified was the reduction in income insecurity. However, respondents frequently mentioned having a parallel career to reduce unemployment or a lack of money because of the risk of resignation.

One reason that emerged in the interviews that was not identified in the literature review involved post-organizational career preparation. Most of the companies in this study had a compulsory retirement age. Parallel careers appeared to be a first step toward this new life stage. This strategy was stimulated by organizations with high levels of internal engagement, which faced resistance to the preparation of successors and needed to share the information and knowledge of people who were retiring due to the compulsory retirement age. In these companies, the idea of a parallel career is suggested a few years before retirement. These companies provide advice and support for professionals in analyzing, choosing, and beginning their new path while they are still working. Once 
they perceive that there is life after retirement, employees feel better about sharing content and preparing their successors. Retirement is no longer perceived as a loss.

"During college, the reason I had parallel careers was due to financial needs, to pay college tuition. After, I continued for the pleasure of it; I was in contact with younger people, I like to teach, to explain. And now I think of it as my post-retirement career." (HR VP and MBA teacher).

"Depending on what someone does, (having parallel careers) is an excellent option for the future, the opening of a new cycle without a crisis when you leave the corporate life." (HR General Manager).

Additional reasons were also found. For several PC holders, the possession of a parallel career was a self-development tool. Because not all competences are needed in all roles, some skills remain undeveloped in some positions, areas, or companies. An additional career that demands competence provides a way of mastering different skills.

In addition to the new reasons that were identified, this study identified some improvements to the initial theories. The work chosen condition can be described in more detail through the analysis of the testimonials. In some cases, respondents cite this reason due to their passion for the subject, which leads to a need for a related formal career. For others, this condition originates from the enjoyment they gain from a specific career.

"(What led me to have this parallel career) was my passion for wine. I travel to France to visit vineyards several times a year, and I take lots of courses. I wanted to have a parallel activity related to that, one thing that I have a great affinity with and that makes me very happy. It gives me the highest pleasure." (CEO, columnist, and entrepreneur).

"The corporate career gives me the base to bring the practice to my students. It is what sustains the link for their learning process. What motivates me is the personal fulfillment. You have to love what you do. I don't see the time pass. I like what I do, I feel pleasure, satisfied with the results of my work. And it is constructed, not immediate." (Specialist and course coordinator).

Another motivation for the work chosen condition reason was the need for different sources. This need is related to an abundance of curiosity and energy and a great desire to go further. People who cite this reason want simultaneous access to more sources of satisfaction, relationships, perspectives, and challenges.

For some respondents, parallel careers are a consequence of the insatiability of the current generation and represent another indication of their impatience in waiting for a traditional and timeconsuming career development path.

\section{Benefits for companies and professionals}

The advantages of parallel careers can be considered the reasons that companies should stimulate or at least allow these careers. Some consequences are positive for both PC holders and their contractors. Because all of the reasons for parallel careers are self-constructed and focus on some type of self-gain, they increase individuals' satisfaction. Because parallel careers are directly related to performance, they are positive for the firm as well. Another shared advantage is that parallel careers help individuals become more proficient professionals. Their different experiences expand PC holders' horizons, providing them with different perceptions and perspectives. Through contact with different people and environments, the professional becomes more flexible and develops a wider repertoire.

"He brings information from the market, new references that the company is not used to. The company wins a lot." (HR Manager).

"Her ability to support people in solving problems as a therapist helps her in doing it better in here (as a T\&D coordinator). She is more up-to-date, flexible, and solves conflicts in a better way." (HR Director).

"I find it very interesting because companies, increasingly quickly, are becoming very demanding and stressful, and the employee does not always have the ability to exercise their potential. By having parallel 
activities, he discovers he has intelligent life outside of the company. He develops new contacts in different environments. This has an effect of reducing the stress of the organization itself." (HR Manager).

"I think it is super healthy. The person broadens her perspective, addresses other groups of people, and the diversity increases. The professional is richer and brings more options for solutions and different references." (HR Director).

In addition to the benefits mentioned above, the PC holder benefits from a new potential career path that he has already tested and that he can continue when his corporate career is over due to retirement requirements. Even if age and law are not issues, the presence of a parallel career reduces dependence on a single employer, allowing an individual to have greater freedom if he is dissatisfied with one career. The existence of a broader network contributes the same benefits.

"I have managed to influence others through my different careers. I am called today to very different jobs outside the current market because of this flexibility." (Head of business unit and international referee).

Several other advantages were identified from the perspective of organizations. The first significant advantage is relevant and valuable with regard to competition for talent in the market. The extension of formal permission to an individual to have parallel careers functions as a retention tool.

"By having the support of the company, I am much more committed. I take care to preserve the relationship. The desire to deliver positive results and maintain the confidence that they have in me is very high. I wouldn't risk losing it.” (Head of business unit and international referee).

Additionally, permission works as an extra source of talent acquisition. New candidates are found through the additional networks provided by employees through their parallel careers. In the same manner, different experiences in dissimilar environments and realities become a cheap source of new competences and a development tool.

"There was a really hard vacancy to be filled. Because he teaches, the director of the position brought several good candidates, his students. His network helped." (HR Manager).

When the reason for managing parallel careers is related to post-corporate career preparation, the preparation of a successor becomes easier, and the resistance level is reduced.

"First, the person will pave the way. The person who is on the program of preparation for retirement does not necessarily have to wait five years to leave the company. Open space for those who are below opens opportunities for other people without having to dismiss. You develop your successor; there is a symbiosis without being dramatic. Today is not the last day of work but the beginning of a new stage. We will get out, but we will prepare replacements." (HR Manager).

A final advantage relates to the reduction of the organization's concerns during massive layoffs. The presence of an additional career moderates an employee's level of dependence on his prior career.

Ultimately, because the organization and the person are interrelated, the benefits that affect one side also produce positive aspects for the other side.

\section{Drawbacks of parallel careers}

From an organizational perspective, five disadvantages were identified. In some cases, the PC holder is perceived as having less flexibility for work travel because of the other career agenda. There is also a risk of conflicts of interest between the different careers. One of the researched companies reduced this risk through the implementation of an Annual Conflict of Interest Declaration, in which all relationships and extra activities are listed by each employee every year. The content is analyzed by the auditing department so that any possible conflict can be identified. If a risk is identified, the employee has a deadline for resolving it, or further action is taken. 
"We have the code of conduct, which sets some limits. You cannot sell your products inside the company. I teach, but I cannot use content related to the firm without permission. Annually, we have to make a declaration of conflicts of interest. You explain to your boss. OK if there is no conflict; if there is, the auditing team analyzes and determines a deadline for it to be resolved. I cannot teach at a university where my company is a client (buying training programs). I can give free lectures there, but I cannot be paid. I cannot do consulting for a competitor." (Operations director, teacher, and member of the counseling board of some companies).

The respondents also noted a risk of not delivering the expected results and the risk of the company's resources being used by the PC holder to perform tasks for the other career. This risk is also present in cases of a second job.

"If not well coordinated, the professional can start using the time and structure of the CIA to do their business. We decided this annually through the declaration of conflict of interest. If he begins to dispute the energy/time/resources of the company, it is prohibited." (HR VP and MBA teacher).

"We had a case of an executive who was a teacher and was preparing lessons here." (HR VP).

Cases of losing the employee to the parallel career were mentioned on multiple occasions. These cases can be viewed as instances of the first step in a career change.

"The downside is losing the person, as happened with the lady who also made cakes. She decided to live just from the cakes." (HR General Manager).

Disadvantages were also mentioned on the individual side. When one of the careers is full time or the combined careers require more hours than a full-time schedule, private life hours are used, which can affect an individual's personal life. Another challenge is to manage the different agendas so that they do not compromise one another and so the resources of one career are not used on behalf of the other. Because commercial hours are essentially the same, in many cases, lunch hours are used, which compromises eating and resting and affects the balance of health and life.

"You must have time; take care not to mix with the work schedule. It is inevitable to have to make calls during business hours, so you have to do it at lunchtime, and eat fast or don't eat." (Accountant manager and entrepreneur in the food sector).

Similarly, another challenge is handling scheduling conflicts. For example, there are cases of two meetings being scheduled at the same time. The examples offered by the respondents indicated that the solution for avoiding this problem involved defining which career would be prioritized. Thus, the idea of a primary career within a set of parallel careers emerges.

\section{Organizational levers and barriers}

During the interviews, the existence or lack of specific mechanisms were identified as contributors or disruptors for PC holders. The existence of the following factors was recognized as important facilitators for parallel careers:

. A formal and respected bank of hours system and flexible working hours;

. Respected working hours;

. Internal practices that encourage a work-life balance;

- Management focused on results rather than on the hours for which the person is physically at the company;

. Home office and technology that makes remote work feasible. 
In contrast, when dedication and recognition are based on the number of hours spent in the office rather than the quality and quantity of results, the successful management of parallel careers becomes more difficult.

In most cases, for PC holders, the possession of parallel careers did not present barriers to hierarchical growth. Many respondents achieved the highest positions in their companies and perceived the multiplicity of skills they gained through their parallel careers as a relevant contributor.

\section{Discussion}

The present research provides insight into the views of organizations regarding PC holders in an attempt to eliminate the literature gap and to contribute to Alboher (2007) and Schuiling's (2012) research. The current study identifies companies' reactions to the topic of parallel careers and explores different career combinations and the reasons individuals pursue them simultaneously. It also describes the additional value that this profile can introduce as well as its drawbacks for both employees and organizations. It suggests mechanisms that can leverage or curb their existence. Because the extant literature does not address the subject of parallel careers in depth, the present discussion focuses on previous studies that have considered topics with similarities to the parallel career phenomenon.

Parallel careers and work-life balance have many aspects in common. They both represent role accumulations (Voydanoff, 2001). The results of the current research indicate that the enriched combination of work-family coexistence (Greenhaus \& Powell, 2006) can be extrapolated to the role accumulation of parallel careers. A positive impact on satisfaction is one example. Another is the valuable effects on physical and psychological well-being (Barnett \& Hyde, 2001); one of their roles may buffer individuals from distress. A strong and healthy work life can help a person to better manage personal life distress and vice versa (Greenhaus \& Powell, 2006). The same applies in the case of distress in one career; the energy to address this distress can be obtained from the other career. Experiences in one role can produce positive experiences and outcomes in the other. These multiple roles represent a transfer of positive experiences in terms of energy (Marks, 1977). As the present research has revealed, role accumulation allows for the transference of social relationships and a reconciliation of discrepant views. Flexibility in adjusting to demands is stimulated by diverse roles (Sieber, 1974).

James-Enger's (2010) empirical data affirm that parallel careers increase employability, autonomy, mental vitality (Ryan \& Frederick, 1997), job satisfaction, risk diversification, and fulfillment for their holders. The current research identified the relationships among parallel careers and job satisfaction, risk diversification, and fulfillment. The other benefits mentioned above were neither denied nor confirmed. Further research can be performed regarding these benefits.

Alboher's (2007) findings that PC holders are able to use their talents and express sides of themselves that might otherwise lie dormant, that they report surprising instances of synergy, and that mastering a work task in one career facilitates the solving of problems in the other seemingly unrelated job were repeatedly supported in the present research as well. It also corroborates James-Enger's (2010) assertion that the simple fact of working in a new field provides new insights and ideas that can be used in the current field. The findings suggest that organizations that support pluralistic concepts of careers have the advantage of developing and maintaining diverse sets of complementary skills and capabilities within their workforce. These skills provide distinct competitive and survival advantages in a fast-moving, unpredictable, and largely unforgiving world (Brousseau, Driver, Eneroth, \& Larson, 1996).

When an organization offers instruments that contribute to the harmonization of work and personal life, employees are likely to be more committed to the organization (Friedman, Christensen, 
\& DeGroot, 1998; Lee \& DeVoe, 2012). Their trust redoubles, as do their loyalty and energy for their work. Unsurprisingly, their performance improves, and the organization benefits. These strong results allow managers to continue to practice the principles that aid employees in achieving this work-life balance. The same principles have been found to apply when extra careers are added as part of one's personal roles. A connection can also be observed in terms of work engagement (Schaufeli, Salanova, González-Romá, \& Bakker, 2002). According to Bakker and Demerouti (2008), performance and work engagement are directly connected by a cause-effect relationship. As a result of job resources, job demands, and personal resources, work engagement leads to better work performance. Engaged employees have high levels of energy and are enthusiastic about their work. Moreover, they are often fully immersed in their work, so the time passes quickly (May, Gilson, \& Harter, 2004). Because parallel careers contribute to more diverse personal and job resources, as this research revealed, these careers can be a source of work engagement and, consequently, high performance for some people.

Based on a comparison of the literature on the mechanisms that leverage or oppose parallel careers and the findings of this study, it is clear that the current study contributes to the literature in several ways. When flexible work practices are effectively implemented, they can be methods of improving organizational outcomes by increasing employee engagement and talent retention (Richman, Civian, Shannon, Hill, \& Brennan, 2008). These practices include various mechanisms, tools, and features that support flexibility in terms of timing (flextime - Bond, Galinsky, Stacy, \& Brownfield, 2005; Hill, Hawkins, Ferris, \& Weitzman, 2001) and work location (flexplace Christensen \& Staines, 1990; Felstead, Jewson, Phizacklea, \& Walters, 2000; Hill et al., 2001; Peters, Bleijenbergh, \& Oldenkamp, 2009). Telecommunication tools also play a major role (Friedman et al., 1998; Rau, 2003; Venkatesh \& Johnson, 2002). Wireless communication gadgets connect users to work, family, and digital information in any location and at all times. Employees can work whenever and wherever they desire and can integrate their work and non-work domains.

These benefits are complemented by practices such as on-site or subsidized child care and elder care, job sharing, part-time employment, dependent care spending accounts, easy access to employee assistance programs, and supervisory training on the importance of a work-life balance (Hobson, Delunas, \& Kesic, 2001; Pas, Peters, Doorewaard, Eisinga, \& Lagro-Janssen, 2011). The present research confirms that for PC holders, flexible work practices represent tools that render parallel careers more feasible. PC holders value these flexible practices as much as workers with children at home do (Hill et al., 2008). The current study's contribution to the literature stems from insights related to work control. When the management system is based on results rather than on the number of hours that are physically spent at the office, parallel careers appear much more feasible. In many cases, this component is more important than all of the other mechanisms.

Different careers can be mutually reinforcing and complementary, but they can also introduce internal conflicts and compete with one another for time, commitment, effort, and energy (Kirton, 2006). Individuals may become overwhelmed with too many projects, may be pulled in many different directions, and may have to spend their own time and money on training and certifications (JamesEnger, 2010). The interviews and analyses confirm that balancing all roles is the most significant challenge of parallel careers. However, the assumption that dedicating working hours and energy to multiple careers delays organizational progress in the primary company (McCormick, 2003) was not confirmed. The findings indicate that parallel careers contributed positively to hierarchical growth. However, this contribution cannot be considered common because ex-PC holders were not interviewed, and these individuals may have become ex-PC holders precisely because they faced delays in their professional evolution. In this case, further research would be useful.

In addition to multiple professional careers, each person has private roles as well, including family, leisure, physical health, and spiritual and social roles. Families need time together to enjoy and learn from one another and to share experiences and values. If the time balance is not well managed and the family loses its share of time, this situation may impair family life (Mackin, 1995) and increase the use of non-parental childcare (Kimmel \& Powell, 1996 as cited in Averett, 2001). Such a deficiency can even lead to the postponement of marriage and child rearing (McCormick, 2003). 
From the organizational perspective, there may be problems with attendance, performance, the disclosure of proprietary information, and employee conflicts. These issues can all be addressed by internal policies that cover situations such as those mentioned. These problems are serious issues in fields in which it is necessary to be alert and physically healthy, as with doctors and nurses, who can compromise patients' lives if they are not well rested and watchful.

\section{Limitations and directions for future research}

This research was limited to companies based in a single country and primarily in one state. As such, the generalizability of the findings is limited. Companies from other Brazilian states and other countries and those experiencing different economic situations should be considered for a broader perception of the subject. In addition, ex-PC holders should be interviewed to enrich the conclusions.

Further research is needed. A quantitative study measuring the most common parallel career combinations and reasons for these combinations would be useful for talent managers in developing more specific action plans and policies to attract and retain this profile. Furthermore, such a study would provide a clearer perspective on the standards for a healthy number of hours committed to each career.

Additionally, longitudinal studies could investigate whether the existence of parallel careers is a growing phenomenon or simply a fad. Such a study could confirm or invalidate parallel careers as a trend. A case study of a promoter company would illustrate the advantages and disadvantages of the experience for the individual and the organization as well as the policies used to avoid possible conflicts.

\section{Academic and managerial implications}

Relatively little data are available regarding parallel careers. This study presents an organizational perspective on this topic and provides insight into how parallel careers work, whether they exist, and how they can be used to attract and retain people, particularly in terms of contributing to human development. Considering the Brazilian labor economic situation, the value of this study is increased because of the difficulty of finding and retaining employees. Companies that are concerned about having the best talent on their teams will benefit from understanding the phenomenon of parallel careers, which may constitute a valuable tool for talent attraction, retention, and development. The latter possibility is particularly important because parallel careers present a new and cheap way to develop new competences.

This study also serves as a new baseline for future research that will confirm, complement, or reject the findings presented above. This study opens a new line of research concerning companies' perspectives on this topic. This consideration of the organizational perspective may stimulate other career studies to present a more systemic approach.

\section{Conclusions}

With respect to parallel careers, the literature is quite limited. To date, there has been little focus on this issue from either an individual or an organizational perspective. The research study reported here indicates that although not all of the companies studied favor the practice, particularly when physical presence is more important than results, those that favor parallel careers clearly perceive their benefits. The issue appears to be when parallel careers will be broadly disseminated rather than whether they are positive or negative. Companies that support parallel careers will enjoy an interest advantage when competing for the best talent. At the same time, work-life issues should not be ignored but should be addressed through the use of specific policies that regulate boundaries. 
The analysis of the reasons for pursuing parallel careers indicates that many of these careers have no turning point; they are a consequence of the multiconnected and multidisciplinary world in which we live. Obvious combinations of parallel careers, such as career $\mathrm{x}+$ teacher or career $\mathrm{y}+$ artist, are being joined by nontraditional ones, such as career $\mathrm{z}+$ doctor. PC holders welcome many of the flexible work tools available (flextime and flexplace) as well as management and assessment in terms of results rather than hours in the office.

\section{References}

Alboher, M. (2007). One person/multiple careers: a new model for work/life success. New York, NY: Warner Business Books.

Amirault, T. (1997). Multiple jobholders: what else do I want to do when I grow up? Occupational Outlook Quarterly, 40(4), 42-47.

Appelbaum, S. H., Bethune, M., \& Tannenbaum, R. (1999). Downsizing and the emergence of selfmanaged teams. International Journal, 7(5), 109-130. doi: 10.1108/14634449910287837

Arthur, M. B. (1994). The boundaryless career: a new perspective for organizational inquiry. Journal of Organizational Behavior, 15(4), 295-306. doi: 10.1002/job.4030150402

Arthur, M. B., \& Rousseau, D. M. (1996). The boundaryless career: a new employment principle for a new organizational era. Oxford: Oxford University Press.

Averett, S. L. (2001). Moonlighting: multiple motives and gender differences. Applied Economics, 33(11), 1391-1410. doi: 10.1080/00036840010007957

Bakker, A. B., \& Demerouti, E. (2008). Towards a model of work engagement. Career Development International, 13(3), 209-223. doi: 10.1108/13620430810870476

Barnett, R. C., \& Hyde, J. S. (2001). Women, men, work, and family: an expansionist theory. American Psychologist, 56(10), 781-796. doi: 10.1037//0003-066X.56.10.781

Bell, D. N., Hart, R. A., \& Wright, R. E. (1997). Multiple job-holding as a 'hedge' against unemployment. Centre for Economic Policy Research Discussion, (1626), 53-59. Retrieved from http://ideas.repec.org/p/cpr/ceprdp/1626.html

Bond, J. T., Galinsky, E., Stacy, S., \& Brownfield, E. (2005). National study of employers. New York, NY: Families and Work Institute.

Boulhol, H. (2009). Do capital markets and trade liberalization trigger labor market deregulation. Journal of International Economics, 77(2), 223-233.

Bradley, H., Healy, G., \& Mukherjee, N. (2005). Multiple burdens: problems of work/life balance for ethnic minority trade union activist women. In D. Houston (Ed.), Work life balance in the 21 st century (pp. 211-229). Basingstoke: Palgrave-Macmillan.

Briscoe, J. P., \& Finkelstein, L. M. (2009). The "new career" and organizational commitment: do boundaryless and protean attitudes make a difference? Career Development International, 14(3), 242-260. doi: 10.1108/13620430910966424

Briscoe, J. P., \& Hall, D. T. (2006). The interplay of boundaryless and protean careers: combinations and implications. Journal of Vocational Behavior, 69(1), 4-18. doi: 10.1016/j.jvb.2005.09.002 
Briscoe, J. P., Hall, D. T., \& DeMuth, R. L. F. (2006). Protean and boundaryless careers: an empirical exploration. Journal of Vocational Behavior, 69(1), 30-47. doi:10.1016/j.jvb.2005.09.003

Brousseau, K. R., Driver, M. J., Eneroth, K., \& Larson, R. (1996). Career pandemonium: realigning organizations and individuals. Academy of Management Executive, 10(4), 52-66.

Cesare, S. J., \& Thornton, C. (1993). Human resource management and the specialist/generalist issue. Journal of Managerial Psychology, 8(3), 31-40. doi: 10.1108/02683949310027763

Christensen, K. E., \& Staines, G. L. (1990). Flextime: a viable solution to work-family conflict? Journal of Family Issues, 11(4), 455-476. doi: 10.1177/019251390011004007

Cole, F.L. (1988). Content analysis: process and application. Clinical Nurse Specialist, 2(1), 53-57. doi: 10.7748/nr1997.04.4.3.5.c5869

Cooper, D. R., \& Schindler, P. S. (2008). Business research methods (10th ed.). London: McGrawHill.

Datta, D. K., Guthrie, J. P., Basuil, D., \& Pandey, A. (2010). Causes and effects of employee downsizing: a review and synthesis. Journal of Management, 36(1), 281-348. doi: $10.1177 / 0149206309346735$

DeFillippi, R. J., \& Arthur, M. B. (1994). The boundaryless career: a competency based perspective. Journal of Organizational Behavior, 15(4), 307-324. doi: 10.1002/job.4030150403

Doherty, N. (1996). Surviving in an era of insecurity. European journal of work and organizational psychology, 5(4), 471-478. doi: 10.1080/13594329608414873

Earle, H. A. (2003). Building a workplace of choice: using the work environment to attract and retain top talent. Journal of Facilities Management, 2(3), 244-257. doi: 10.1108/14725960410808230

Felstead, A., Jewson, N., Phizacklea, A., \& Walters, S. (2000). A statistical portrait of working at home in the UK: evidence from the labour force survey [Working Paper N. 4]. ESRC Future of Work Program, Leicester, LE, UK.

Friedman, S. D., Christensen, P., \& DeGroot, J. (1998). Work and life: the end of the zero-sum game. Harvard Business Review, 76(6), 119-129.

Greenhalgh, L., \& Rosenblatt, Z. (2010). Evolution of research on job insecurity. International Studies of Management \& Organization, 40(1), 6-19. doi: 10.2753/IMO0020-8825400101

Greenhaus, J. H., Callanan, G. A., \& DiRenzo, M. S. (2008). A boundaryless perspective on careers. In C. L. Cooper \& J. Barling (Eds.), Handbook of organizational behavior (pp. 277-299). Thousand Oaks, CA: Sage.

Greenhaus, J. H., \& Powell, G. N. (2006). When work and family are allies: a theory of work-family enrichement. Academy of Management Review, 31(1), 72-92. doi: 10.2307/20159186

Hall, D. T. (1976). Careers in organizations. Glenview, IL: Scott, Foresman.

Hall, D. T. (1996). Protean careers of the 21 st century. Academy of Management Executive, 10(4), 816. doi:10.5465/AME.1996.3145315

Hall, D. T. (2004). The protean career: a quarter-century journey. Journal of Vocational Behavior, 65(1), 1-13. doi:10.1016/j.jvb.2003.10.006

Hay, M. (2002). Strategies for survival in the war for talent. Career Development International, 7(1), 52-55. doi: 10.1108/13620430210414883 
Herriot, P., \& Pemberton, C. (1995). New deals: the revolution in managerial careers. Chichester, UK: Wiley.

Hill, E. J., Hawkins, A. J., Ferris, M., \& Weitzman, M. (2001). Finding an extra day a week: the positive influence of perceived job flexibility on work and family life balance. Family Relations, 50(1), 49-58. doi: 10.1111/j.1741-3729.2001.00049.x

Hill, E. J., Jacob, J. I., Shannon, L. L., Brennan, R. T., Blanchard, V. L., \& Martinengo, G. (2008). Exploring the relationship of workplace flexibility, gender, and life stage to family-to-work conflict, and stress and burnout. Community, Work \& Family, 11(2), 165-181. doi: $10.1080 / 13668800802027564$

Hobson, C. J., Delunas, L., \& Kesic, D. (2001). Compelling evidence of the need for corporate work/life balance initiatives: results from a national survey of stressful life-events. Journal of Employment Counseling, 38(1), 38-44. doi: 10.1002/j.2161-1920.2001.tb00491.x

James-Enger, K. (2010). A second career can boost your writing: 4 freelancers offer solid tips for branching out into a complementary field. Writer, 123(8), 41-42.

Kimmel, J., \& Conway, K. S. (2001). Who moonlights and why? Evidence from the SIPP. Industrial Relations: A Journal of Economy and Society, 40(1), 89-120. doi: 10.1111/0019-8676.00198

Kimmel, J., \& Powell, L. (1996, June). A comparative analysis of moonlighting and related policy issues in Canada and the United States. Proceedings of the The Canadian Employment Research Forum (CERF), in cooperation with the W. E. Upjohn Institute for Employment Research, Statistics Canada, and Human Resources Development Canada, Ottawa, Ontario, Canada.

Kirton, G. (2006). Alternative and parallel career paths for women: the case of trade union participation. Work, Employment \& Society, 20(1), 47-65. doi: 10.1177/0950017006061273

Klehe, U.-C., Zikic, J., Van Vianen, A. E. M., \& De Pater, I. E. (2011). Career adaptability, turnover and loyalty during organizational downsizing. Journal of Vocational Behavior, 79(1), 217-229. doi: 10.1016/j.jvb.2011.01.004

Krippendorff, K. (2012). Content analysis: an introduction to its methodology. Newbury Park: Sage Publications.

Krugman, P. (2009, July 2). That 30's show. New York Times, p. A27.

Layder, D. (1993). New strategies in social research. London: Polity Press.

Lee, B. Y., \& DeVoe, S. E. (2012). Flextime and profitability. Industrial Relations: A Journal of Economy and Society, 51(2), 298-316. doi: 10.1111/j.1468-232X.2012.00678.x

Libera, M. C. D. (2011, July). The concept of dual career ladder and talent retention - Recognizing the differences between specialists and generalists contributes to attract and retain talents. Revista BSP. [Web log post]. Retrieved from http://www.revistabsp.com.br/edicao-julho2011/en/2011/07/27/carreira-em-\%E2\%80\%9Cy\%E2\%80\%9D-e-retencao-de-talentosreconhecer-as-diferencas-entre-especialistas-e-generalistas-contribui-para-atracao-e-retencaode-talentos/

Livanos, I., \& Zangelidis, A. (2012). Multiple job-holding among male workers in Greece. Regional Studies, 46(1), 119-135. doi: 10.1080/00343404.2010.486780

Lundborg, P. (1995). Job amenity and the incidence of double work. Journal of Economic Behaviour and Organization, 26(2), 273-287. doi: 10.1016/0167-2681(94)00022-7

Mackin, J. (1995). Three jobs are too many for a family. Human Ecology, 23(1), 2. 
Marion, K. (2009, August 17). What is a 'parallel career' and do I need one? Examiner.com. [Web log post]. Retrieved from http://www.examiner.com/college-to-career-in-denver/what-is-a-parallelcareer-and-do-i-need-one

Marks, S. R. (1977). Multiple roles and role strain: some notes on human energy, time and commitment. American Sociological Review, 42(6), 921-936.

Martel, J. (2000, October). Reasons for working multiple Jobs. Monthly Labor Review, pp. 42-43.

May, D. R., Gilson, R. L., \& Harter, L. M. (2004). The psychological conditions of meaningfulness, safety and availability and the engagement of the human spirit at work. Journal of Occupational and Organizational Psychology, 77(1), 11-37. doi: 10.1348/096317904322915892

McCormick, B. (2003). Two jobs are better than one. Crain's Chicago Business, 26(32) SB6-SB10.

Michaels, E., Handfield-Jones, H., \& Axelrod, B. (2001). The war for talent. Boston: Harvard Business School Press.

Moncarz, E., Zhao, J., \& Kay, C. (2009). An exploratory study of US lodging properties' organizational practices on employee turnover and retention. International Journal of Contemporary Hospitality Management, 21(4), 437-458. doi: 10.1108/09596110910955695

Nilsson, S., \& Ellström, P.-E. (2011). Employability and talent management: challenges for HRD practices. European Journal of Training and Development, 36(1), 26-45. doi: $10.1108 / 03090591211192610$

Noe, R. (2002). Employee training \& development (2nd ed.). Boston: McGraw-Hill.

Pas, B., Peters, P., Doorewaard, H., Eisinga, R., \& Lagro-Janssen, T. (2011). Feminisation of the medical profession: a strategic HRM dilemma? The effects of family friendly HR practices on female doctors' contracted working hours. Human Resources Management Journal, 21(3), 285302. doi: $10.1111 / \mathrm{j} .1748-8583.2010 .00161 . \mathrm{x}$

Peters, P., Bleijenbergh, I., \& Oldenkamp, E. (2009). Cultural sources of variance in telework adoption in two subsidiaries of an ICT - multinational. International Journal of Employment Studies, 17(2), 66.

Rau, B. L. (2003). Flexible work arrangements. Sloan Online Work and Familiy Encyclopedia. [Web $\log$ post]. Retreived from https://workfamily.sas.upenn.edu/wfrn-repo/object/h94f69es38oo6k6s

Reilly, A. H., Brett, J. M., \& Stroh, L. K. (1993). The impact of corporate turbulence on managers' attitudes. Strategic Management Journal, 14(S1), 167-179. doi: 10.1002/smj.4250140913

Richman, A. L., Civian, J. T., Shannon, L. L., Hill, E. J., \& Brennan, R. T. (2008). The relationship of perceived flexibility, supportive work-life policies, and use of formal flexible arrangements and occasional flexibility to employee engagement and expected retention. Community, Work \& Family, 11(2), 183-197. doi: 10.1080/13668800802050350

Robbins, S. P. (1999). Lay-off survivor sickness: a missing topic in organizational behavior. Journal of Management Education, 23(1), 31-43. doi: 10.1177/105256299902300104

Ryan, R., \& Frederick, C. (1997). On energy, personality, and health: subjective vitality as a dynamic reflection of well-being. Journal of Personality, 65(3), 529-565. doi: 10.1111/j.14676494.1997.tb00326.x

Rynes, S. L., \& Cable, D. (2003). Recruitment research in the twenty-first century. In W. C. Borman, D. R. Ilgen, R. J. Klimoski, \& I. B. Weiner (Eds.), Handbook of psychology: industrial and organizational psychology (Vol. 12, pp. 55-76). Hoboken, NJ: Wiley. 
Schaufeli, W. B., Salanova, M., González-Romá, V., \& Bakker, A. B. (2002). The measurement of engagement and burnout: a two sample confirmatory factor analytic approach. Journal of Happiness Studies, 3(1), 71-92. doi: 10.1023/A:1015630930326

Schuiling, G. (2012). Helpen combibanen bij het overbruggen van grenzen? Rollen combineren in elkaar vreemde werelden. $O \& O$ (Organisation \& Development), (5), 27-32.

Segers, J., Inceoglu, I., Vloeberghs, D., Bartram, D., \& Henderickx, E. (2008). Protean and boundaryless careers: a study on potential motivators. Journal of Vocational Behavior, 73(2), 212-230. doi: 10.1016/j.jvb.2008.05.001

Shishko, R., \& Rostker, B. (1976). The economics of multiple job holding. The American Economic Review, 66(3), 298-308.

Sieber, S. D. (1974). Toward a theory of role accumulation. American Sociological Review, 39(4), 567-578. doi: 10.2307/2094422

Strauss, A., \& Corbin, J. (2008). Basics of qualitative research (3rd ed.). Thousand Oaks, CA: Sage.

Sullivan, S. E. (1999). The changing nature of careers: a review and research agenda. Journal of Management, 25(3), 457-484. doi: 10.1177/014920639902500308

Sullivan, S. E., \& Arthur, M. B. (2006). The evolution of the boundaryless career concept: examining physical and psychological mobility. Journal of Vocational Behavior, 69(1), 19-29. doi:10.1016/j.jvb.2005.09.001

Sullivan, S. E., \& Baruch, Y. (2009). Advances in career theory and research: a critical review and agenda for future exploration. Journal of Management, 35(6), 1542-1571. doi: $10.1177 / 0149206309350082$

The Economist. (1999, January 28). Overworked and overpaid: the American manager. The Economist, pp. 61-62.

Venkatesh, V., \& Johnson, P. (2002). Telecommuting technology implementations: a within and between-subjects longitudinal field study. Personnel Psychology, 55(3), 661-687. doi: $10.1111 / j .1744-6570.2002 . t b 00125 . x$

Verbruggen, M. (2012). Psychological mobility and career success in the 'new' career climate. Journal of Vocational Behavior, 81(2), 289-297. doi: 10.1016/j.jvb.2011.10.010

Voydanoff, P. (2001). Incorporating community into work and family research: a review of basic relationships. Human Relations, 54(12), 1609-1637. doi: 10.1177/00187267015412003

Wajcman, J., \& Martin, B. (2001). My company or my career: managerial achievement and loyalty. The British Journal of Sociology, 52(4), 559-578. doi: 10.1080/00071310120084472

Wu, Z., Baimbridge, M., \& Zhu, Y. (2009). Multiple job holding in the United Kingdom: evidence from the British household panel survey. Applied Economics, 41(21), 2751-2766. doi: $10.1080 / 00036840701335520$ 